Chirurgia (2020) 115: 493-504

No. 4, July - August

Copyright@ Celsius

http://dx.doi.org/10.21614/chirurgia.115.4.493

\title{
Which is the Optimal Method of Reconstruction After Laparoscopic Right Hemicolectomy, the Intracorporeal or Extracorporeal Anastomosis Technique?
} Technical Considerations, Lessons Learned and Review of the Literature

\author{
Vlad Fagarasan', Andreea Cordos', Cristina Petrisor', Adriana Bintintan², Romeo Chira ${ }^{2}$, Felix Nickel ${ }^{3}$, \\ Valeriu Surlin ${ }^{4}$, George Dindelegan', Vasile Bintintan ${ }^{1 *}$
}

\begin{abstract}
${ }^{1} 1$ st Surgical Clinic, University of Medicine and Pharmacy Cluj Napoca, Romania
${ }^{2} 1$ st Medical Clinic, University of Medicine and Pharmacy Cluj Napoca, Romania

${ }^{3}$ Clinic for General, Visceral and Transplantation Surgery, University of Heidelberg, Germany

${ }^{4} 1$ st Clinic of Surgery, University of Medicine and Pharmacy Craiova, Romania
\end{abstract}

${ }^{*}$ Corresponding author: Vasile Bintintan M.D. PhD

University of Medicine and

Pharmacy Cluj Napoca

$1^{\text {st }}$ Clinic of Surgery

3-5 Clinicilor Street, 400006

Cluj Napoca

E-mail: Vasile.bintintan@umfcluj.ro

\section{Abbreviations:}

EA - extracorporeal anastomosis

IA - intracorporeal anastomosis

ERAS - enhanced recovery after surgery

SSI - surgical site infection

CO2 - carbon dioxide

$\mathrm{L}-\mathrm{L}$ - latero - lateral

$\mathrm{T}-\mathrm{L}-$ termino - lateral

$\mathrm{T}-\mathrm{T}$ - termino - terminal

Received: 18.05 .2020

Accepted: 08.07.2020

\section{Rezumat}

Care este abordul optim de realizare a anastomozei după hemicolectomia dreaptă laparoscopică, intracorporeal sau extracorporeal?

Considerații tehnice, experiența personală și review al literaturii

Introducere:Abordul laparoscopic pentru hemicolectomia dreaptă a intrat deja în practica chirurgicală curentă însă există în continuare dezbateri privind modalitatea optimă de realizare a anastomozei ileocolice. Studiul de față îşi propune să evalueze critic cele două tehnici utilizate în prezent în cadrul hemicolectomiei drepte laparoscopice, prin abord extracorporeal (EA) respectiv intracorporeal (IA). Material şi metodă: Aspectele tehnice ale celor două procedee anastomotice sunt descrise în detaliu. Datele perioperatorii ale unei cohorte de pacienți consecutivi la care s-a efectuat hemicolectomie dreaptă au fost înregistrate retrospectiv şi analizate în ceea ce priveşte tipul de anastomoză folosit, dinamica tranziției de la EA spre IA şi incidența complicațiilor postoperatorii. La final a fost realizată o analiză a trialurilor clinice randomizate, meta-analizelor si review-urilor din literatură care au evaluat comparativ tehnicile EA şi IA, pentru a integra datelor studiului într-un context mai larg.

Rezultate: EA a fost utilizată preponderent la începutul studiului însă a pierdut teren în ultimii ani în favoarea IA care a devenit tehnica preferată. $\mathrm{Nu}$ s-au înregistrat fistule anastomotice în grupul laparoscopic însă în studiul nostru IA a fost în mod 
surprinzător asociată cu o incidență mai mare a folosirii drenajului peritoneal, a ileusului prelungit, a infecțiilor de plagă, hemoragiilor de la nivelul anastomozei şi chiloperitoneului. Totuşi, IA permite o vizualizare mai bună a bonturilor ileal şi colonic, evită torsionarea partenerilor anastomotici, previne leziunile vasculare sau ale mezenterului asociate extragerii prin minilaparotomie şi este asociată cu un risc mai redus de eventrație postoperatorie. Datele din literature arată de asemenea că IA este de regulă asociată cu reluarea mai precoce a tranzitului intestinal precum şi cu reducerea ratei morbidității şi diminuarea intensității durerilor postoperatorii.

Concluzii: Studiul de față şi datele din literatură arată că în prezent IA nu poate fi considerată drept standardul terapeutic în hemicolectomia dreaptă laparoscopică. Decizia de a efectua anastomoza tip EA sau IA aparține in final chirurgului şi este influențată de experiența şi abilitățile sale tehnice. Trialurile clinice randomizate aflate în curs de desfăşurare ar putea aduce clarificări suplimentare în acest sens în viitor.

Cuvinte cheie: chirurgia laparoscopică, hemicolectomia dreaptă, anastomoză intracorporeală

\begin{abstract}
Introduction: The laparoscopic approach to right colectomy is gradually gaining a leading role in the surgical treatment of right colonic diseases. However, not all aspects of the procedure are standardized and the method of reconstruction of the digestive tract is still under debate. The present study critically evaluates the extracorporeal (EA) and intracorporeal (IA) techniques used for creation of the ileocolic anastomosis during a laparoscopic right colectomy.

Material and Method. The EA and IA anastomotic techniques are described in detail. The perioperative data of a cohort of consecutive patients operated by our surgical team was retrospectively recorded and analyzed regarding type of anastomosis, the path for transition from EA to IA and the incidence of postoperative complications. Furthermore, an analysis of randomized clinical trials, reviews and meta-analyses that provided a comparative evaluation of EA versus IA was performed to provide a more in-depth integration of our own data into the literature.

Results: EA was used at the beginning of our experience but was later replaced by IA which became the favorite anastomotic technique. There was no anastomotic fistula recorded in the EA or IA groups but in our cohort IA was unexpectedly associated with higher incidence of peritoneal drainage, prolonged ileus, surgical site infections, anastomotic bleeding and chyloperitoneum. However, IA allows better visualization of the ileal and colonic stumps, avoids twisting of the anastomosis, prevents extraction-related tearing of the mesocolon and reduces the risk of postoperative hernia. Data from the literature also shows that IA is generally associated with earlier postoperative return of bowel function, less morbidity and less postoperative pain.

Conclusions: Based on this study and the data currently present in the literature it can not be concluded that IA should be considered as the standard of care for laparoscopic right colectomy. The decision for an EA or IA anastomosis ultimately belongs to the surgeon and is influenced by his surgical skill and experience. The results of ongoing randomized controlled trials on large group of patients may bring more clarity on this issue in the future.
\end{abstract}

Key words: laparoscopic surgery, right colectomy, intracorporeal anastomosis

\section{Introduction}

Colorectal cancer is the third most commonly diagnosed malignancy in males and the second in females. Approximately one third of these cases are located into the right colon. Despite recent advances in surgical technique and increasingly efficient chemotherapy regimens, 
this disease is still associated with a significant mortality (1).

The laparoscopic right hemicolectomy is associated with less postoperative pain, faster recovery and shorter hospital stay while maintaining similar long-term survival rates compared to the open approach (2-10). Despite being a well standardized procedure, the optimal method of reconstruction of the digestive tract continuity is still under debate. There are two main possibilities to create the anastomosis, either through an extracorporeal or an intracorporeal approach. Each of them offers excellent results but also demonstrates individual characteristics that may bring additional advantages to a specific patient. However, currently there are no definitive recommendations regarding the technique which should be used in general or in a particular intraoperative situation.

The present study describes in detail the two anastomotic techniques and discusses their indications, advantages and disadvantages as they are observed by the authors and revealed by the literature. In the end, an attempt will be made to offer guidelines for selection of the optimal approach to be used in the clinical practice.

\section{Aim of the Study}

\section{Primary Endpoint}

The main aim of this study is to evaluate the incidence of EA and IA techniques in laparoscopic right colectomy on consecutive cases operated by our surgical team between October 2014 and February 2020 and to determine if there is a particular recommendation for the use of either EA or IA in a specific patient.

\section{Secondary Endpoint}

The secondary endpoint of the study was to analyze the perioperative morbidity associated with EA and IA respectively. In this regard the following complications were recorded: anastomotic leak, surgical site infection (SSI), pro- $^{-}$ longed postoperative ileus, anastomotic bleeding, chyloperitoneum and incisional hernia.

\section{Tertiary Endpoint}

An analysis of relevant data comprising largecohort studies and randomized controlled trials currently available in the literature comparing the outcomes after EA and IA anastomoses was performed to increase the validity of recommendations for the use of these techniques after laparoscopic right hemicolectomy.

\section{Materials and Methods}

\section{Ileocolic Anastomotic Techniques. \\ Technical Considerations}

After division of the ileocolic, right colic and right branch of the middle colic vessels and mobilization of the right colon along the fascia of Toldt through a medial to lateral dissection, the specimen remains attached only by the continuity of the ileum and the transverse colon. At this stage of the operation a decision should be made regarding the anastomotic technique used to reconstruct the digestive tract. Two main options are available: an extracorporeal or an intracorporeal approach.

\section{Type 1 - The Extracorporeal Anastomosis (EA)}

The ileum and transverse colon are not divided during the laparoscopic phase of the operation as the continuity with the specimen is used to extract the latter outside the peritoneal cavity through a mini-laparotomy. The site of this mini-laparotomy is dictated by the mobility of the transverse mesocolon since the ileal mesentery is extensively dissected off the retroperitoneum and the terminal ileum is mobile enough to be extracted through virtually any site on a $15-20 \mathrm{~cm}$ radius around the umbilicus. As the left branch of the middle colic artery is generally preserved, the remaining transverse colon is still attached to the retroperitoneum and thus has limited mobility. In obese patients this mobility is further reduced by the fatty infiltration of the mesentery and therefore the site of the minilaparotomy should be carefully chosen to permit exteriorization of a segment of the 
colon long enough to allow safe creation of the ileocolic anastomosis. The type of minilaparotomy, either transverse or midline, also needs to be decided. A supraumbilical transverse mini-laparotomy placed on the line of topographic projection of the transverse colon is the most appropriate, allowing extraction of the colon without excessive traction on the mesentery and reducing the risk of postoperative incisional hernia. Placement of a midline mini-laparotomy into the umbilical region is often reported in the literature and is favored by some authors for its improved cosmesis but in our opinion has two major disadvantages: 1) given the increased distance from the umbilicus to the retroperitoneal attachment of the transverse mesocolon and the limited length of the middle colic artery it is often difficult to extract the colon at this site and 2) it carries an increased risk of postoperative hernia.

Once the specimen is extracted outside the peritoneal cavity, the ileum and colon are divided and a T-T, L-T or L-L, single or double layer, hand-sewn or stapled ileo-colic anastomosis is performed in conventional fashion at the discretion of the surgeon. Finally, the mesenteric defect should ideally be closed. Partial closure of the mesenteric defect towards the bowel side is possible through the mini-laparotomy itself but completion of the suture requires a laparoscopic approach. After completion of the anastomosis, the minilaparotomy is closed, $\mathrm{CO} 2$ is re-insufflated into the peritoneal cavity, closure of the mesenteric defect is finalized and the peritoneal cavity is inspected. A drain is left in place at the discretion of the surgeon, although this has become an increasingly rare event in the era of ERAS recommendations.

\section{Type 2 - The Intracorporeal Anastomosis (IA)}

The stump of the transverse colon is not extracted outside the abdominal cavity and does not require extensive dissection off the retroperitoneum. The colon and the ileum can therefore be divided earlier during the dissection phases of the operation. The specimen is retracted from the operative field, usually into
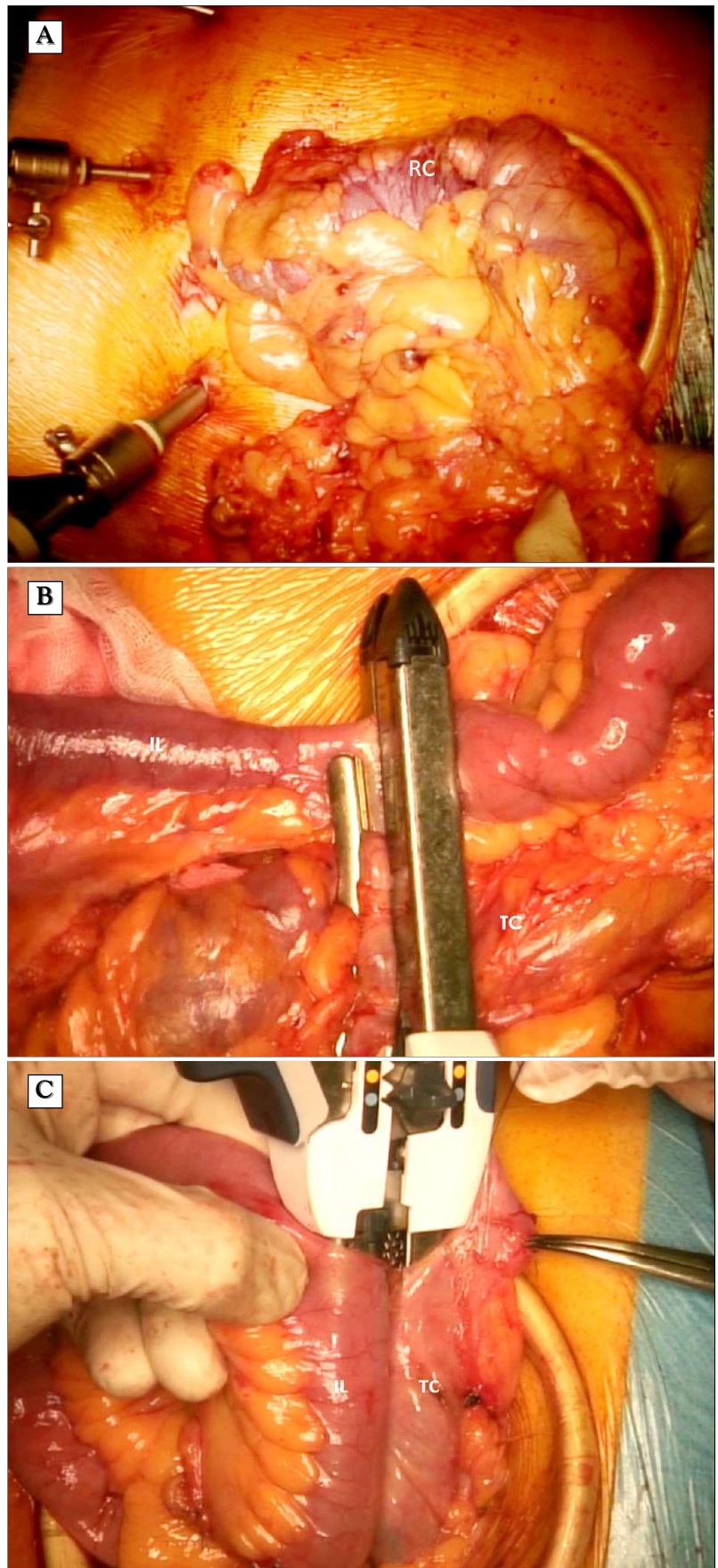

Figure 1. Type I - Extracorporeal anastomosis technique.

(A) Extraction of the specimen through a transversal supraumbilical left-paramedian mini-laparotomy after laparoscopic mobilization of the right colon with total mesocolic dissection; (B) Division of the bowel segments using a linear stapler; (C) Stapled $\mathrm{L}-\mathrm{L}$ isoperistaltic ileo-transverse anastomosis;

$\mathrm{RC}$ - right colon, IL - terminal ileum, TC - transverse colon

the pelvis, and the ileal and colonic stump are placed parallel to one another under direct 

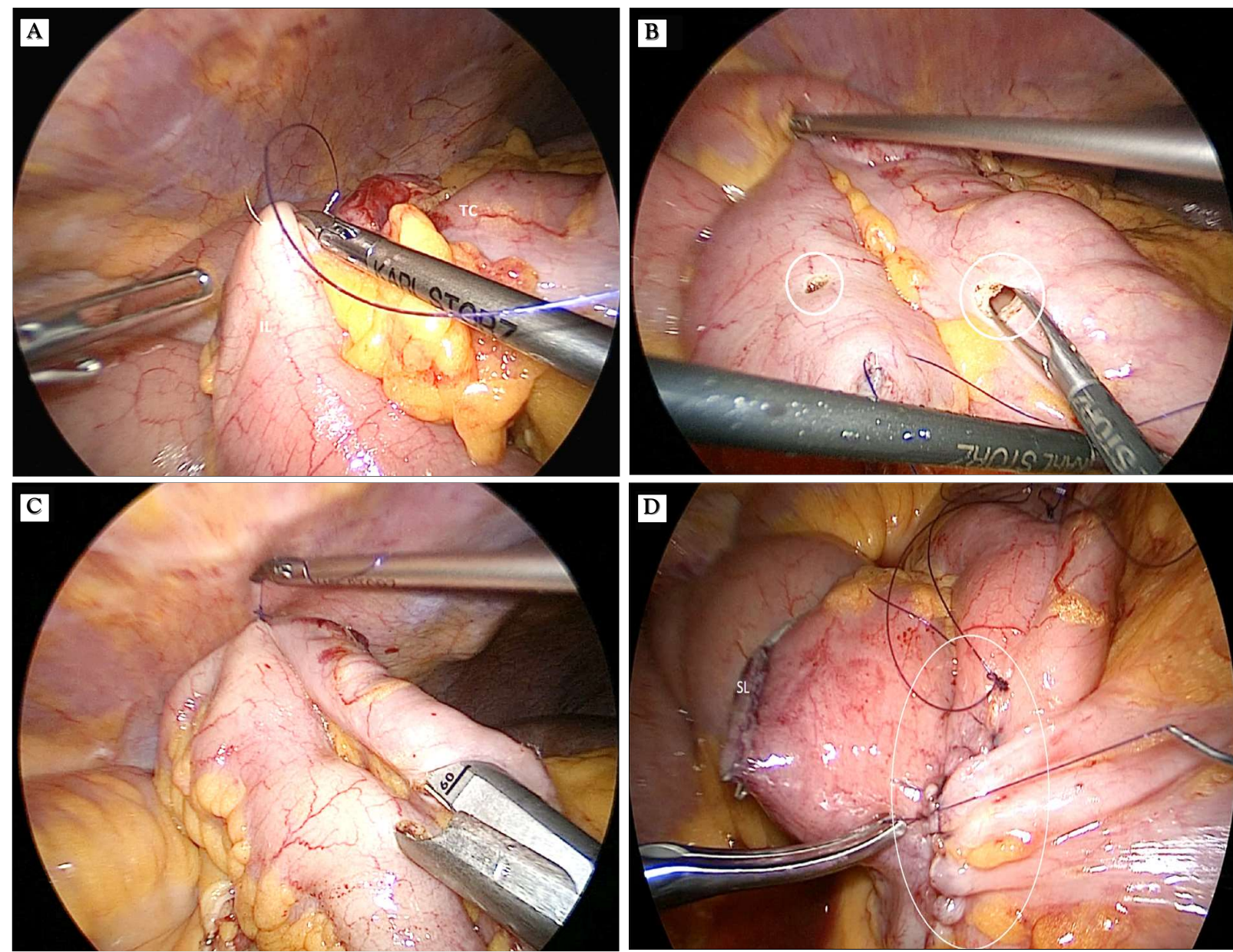

Figure 2. Type II - Intracorporeal anastomosis technique

(A) Placement of stay sutures on the distal corner of the anastomosis; (B) Incision of the bowel segments $3 \mathrm{~cm}$ from the proximal stay suture; (C) Introduction of the stapler into the bowel limbs; (D) Suture of the bowel defect - first layer, full-thickness;

IL - terminal ileum; TC - transverse colon; SL - staple line

laparoscopic visual control. The stapled intracorporeal anastomosis is usually performed in a L-L isoperistaltic fashion. A less technically demanding antiperistaltic $\mathrm{L}-\mathrm{L}$ anastomosis is also possible but has the disadvantage of resulting in an area of staple line crossing which is known to be a weak healing point. Creation of the isoperistaltic L-L anastomosis goes through a series of check-points: 1) two stay sutures are placed, one distal and the other one proximal to the future anastomosis; 2) two $1-\mathrm{cm}$ long incisions are placed, one on the antimesenteric border of the ileum and the other one along the antimesenteric tenia of the transverse colon, roughly $3 \mathrm{~cm}$ distal to the proximal stay suture. The jaws of a $60 \mathrm{~mm}$ articulated endoscopic stapler are introduced through these incisions and the stapler is advanced endolumenally and closed carefully on the antimesenteric side of the bowel, taking care to include equal lengths of the two bowel limbs. After activation of the stapler and creation of the anastomosis, the internal site of the anastomosis is inspected endolumenally with the laparoscope to identify bleeding points that should be stopped with hemostatic stitches or clips - coagulation is discouraged due to the risk of burning tissue included in the anastomosis by thermal spread through the titanium staples. If bleeding is not stopped intraoperatively it may become clinically significant in the first postoperative days, 
eventually requiring a hemostatic colonoscopy. Once the integrity of the anastomosis is verified, the remaining defect must be closed using intracorporeal suturing techniques. Our protocol is to start in the proximal and distal corners of the defect with two full-thickness running sutures that will meet in the midline. A second sero-muscularis layer is performed in a similar fashion. The mesenteric defect is sutured intracorporeally with care taken to avoid injury to the superior mesenteric vein and the middle colic vessels, given the proximity of these structures to the edges of the dissection plane when a three-field total dissection of the right mesocolon is performed. The peritoneal cavity is inspected and a drain is left in place, if desired. The specimen is extracted through a Pfannenstiel laparotomy. There is no need to return to a laparoscopic phase once the mini-laparotomy is closed.

\section{Data Recording for the Laparoscopic Right Colectomy Cohort}

In the study were included consecutive patients that required laparoscopic right colectomy and were operated by our surgical team in the Surgical Clinic No.1 Cluj Napoca during October 2014 and February 2020. Perioperative data was collected by analyzing the patient's files stored in the hospital's electronic database (AtlasMed $\left.{ }^{\mathbb{}}\right)$. The following parameters were recorded: i) intraoperative data: type of operation open or laparoscopic, type of ileocolic anastomosis after laparoscopic right colectomy (EA or IA), type of suturing to create the anastomosis (stapled or hand-sewn), use of peritoneal cavity drainage at the end of surgery; ii) postoperative data: presence of anastomotic leak, surgical site infections (SSI), prolonged postoperative ileus, anastomotic bleeding, chyloperitoneum and length of postoperative hospital stay. Long-term data was collected on the incidence of incisional hernia based on recordings of follow-up visits in the outpatient clinic. Data for the open operated patients was also collected for comparison. Analysis of data was descriptive.

\section{Review of the Literature}

The Pubmed electronic database was searched for the following key-words: laparoscopic right colectomy, right hemicolectomy, ileocolic anastomosis, intracorporeal anastomosis, extracorporeal anastomosis. The papers selected for review had to fulfill the following criteria: i) to provide a comparative analysis of intracorporeal versus extracorporeal anastomosis and ii) to be in one of the following categories: randomized controlled trial, systematic review or meta-analysis.

\section{Results}

\section{Laparoscopic Right Colectomy Cohort}

41 consecutive patients requiring right colec- $^{-}$ tomy were included in the analysis. 16 of them were operated using a minimally-invasive approach. Half of the laparoscopic operated patients had an EA anastomosis (Table 1). The IA anastomosis was firstly performed in 2017 and since 2018 it became the preferred approach (Fig. 3). The ileo-colic anastomosis was hand-sewn in one of the EA cases (12.5\%) and 8 of the open cases (32\%). All other patients had a stapled anastomosis. There was one leak of a stapled anastomosis in a patient from the open group. None of the EA or IA anastomosis patients developed fistula. 11 patients $(27 \%)$ developed a postoperative

Table 1. Characteristics and outcome of the right hemicolectomy cases

\begin{tabular}{lccc}
\hline & Open & \multicolumn{2}{c}{ Laparoscopic } \\
\hline No. of cases (\%) & & EA & IA \\
\hline Stapled anastomosis & $25(60 \%)$ & $8(20 \%)$ & $8(20 \%)$ \\
\hline Drainage & $17(68 \%)$ & $7(87 \%)$ & $8(100 \%)$ \\
\hline Anastomotic leak & $23(92 \%)$ & $3(37 \%)$ & $6(73 \%)$ \\
\hline SSI & $1(4 \%)$ & 0 & 0 \\
\hline Prolonged ileus & $9(36 \%)$ & 0 & $2(25 \%)$ \\
\hline Anastomotic bleeding & $7(28 \%)$ & $1(12 \%)$ & $2(25 \%)$ \\
\hline Chyloperitoneum & $1(4 \%)$ & 0 & $1(12 \%)$ \\
\hline Incisional hernia & $4(16 \%)$ & 0 & $1(12 \%)$ \\
\hline EA & $1(12 \%)$ & 0 \\
\hline
\end{tabular}

EA - extracorporeal anastomosis, IA - intracorporeal anastomosis,

SSI - surgical site infections 
Figure 3. Dynamics of surgical approach and use of $E A$ or IA techniques in laparoscopic right colectomy between 2014-2020

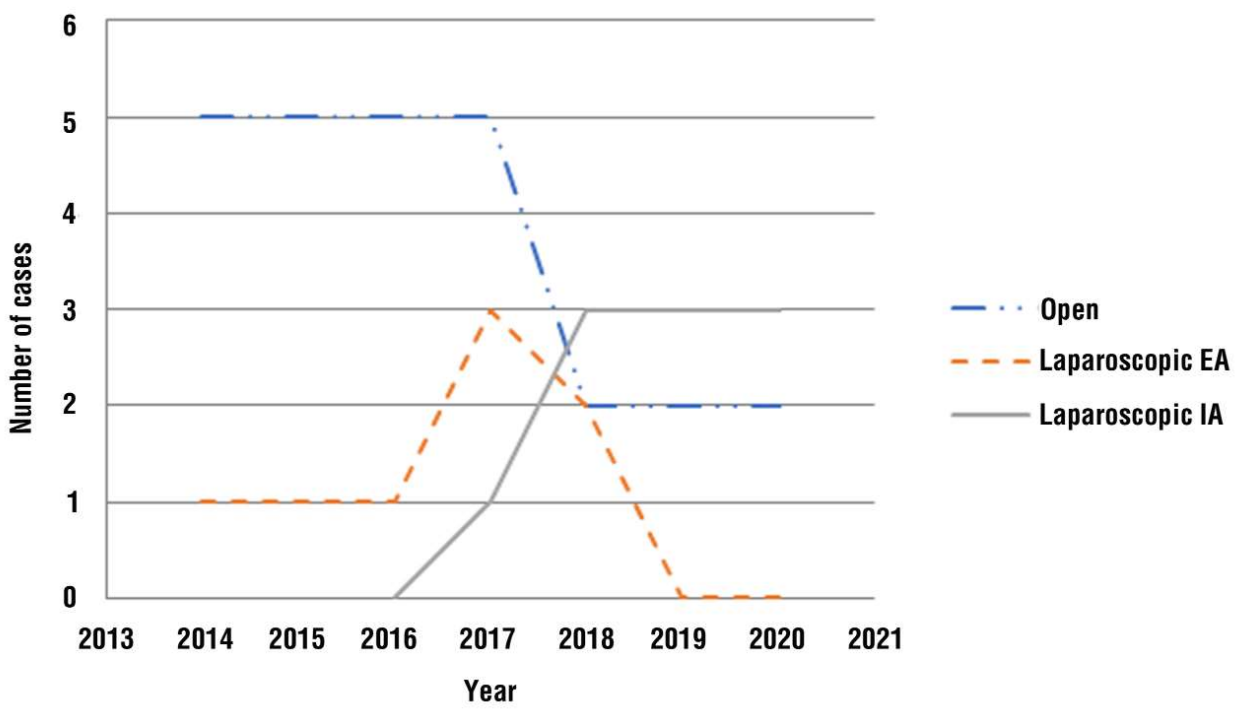

surgical site infection, 9 in the open group (36\% of open cases) and 2 in the laparoscopic IA group ( $25 \%$ of IA cases). The abdominal wall was adequately protected with a Mobius ${ }^{\circledR}$ wound protector in all EA or IA cases. Prolonged ileus developed in 10 patients, 7 in the open group (28\%) and 3 in the laparoscopic group (18\%), of which 2 in the IA group and 1 in the EA group, respectively. A drain was omitted at the end of the operation in 9 patients (22\%), 2 in the open group (8\%), 5 in the EA group (62\%) and 2 in the IA group (25\%). Two patients, both with stapled anastomosis, had endolumenal postoperative bleeding that required endoscopic hemostasis, 1 in the open group and 1 in the IA group.

The postoperative length of stay was longer in the IA group (14.66 days IA vs. 8.7 days EA) due to 2 cases with SSI that required vacuumtherapy followed by suture of the wound in a secondary procedure (19 and 36 days hospital stay), respectively. Other causes for prolonged postoperative length of stay were anastomotic fistula (1 patient in the open group - 34 days), prolonged ileus that resolved with conservative measures, postoperative chyloperitoneum, postoperative bleeding and domicile in remote areas with difficult access to medical care. One patient in both open and laparoscopic groups developed chyloperitoneum (following exten- sive total mesocolic excision of the right colon) that required surgical re-exploration. One patient from the EA group (obese, $\mathrm{BMI}=36.2$ $\mathrm{kg} / \mathrm{m}^{2}$ ) developed a long-term post-operative incisional hernia following a $6 \mathrm{~cm}$ paramedian transverse supraumbilical mini-laparotomy.

\section{Review of the Literature}

The literature search identified 9 papers that fulfilled the inclusion criteria. Of these, 6 were reviews and systematic reviews, one was a metaanalysis and the last two were randomized controlled trials. Generally there was no difference in the incidence of anastomotic leak between the EA and IA groups, however the IA approach seems to be associated with fewer SSI, quicker return of bowel function, shorter hospital stay, lower morbidity and better pain score (Table 2). The detailed results of each paper will be further analyzed in the discussion chapter.

\section{Discussions}

Our surgical team started performing laparoscopic right hemicolectomy in 2008 , using the Type I extracorporeal anastomotic technique (EA). There were several reasons for this choice: i) similarities with the open technique; 
Table 2. A summary of large-cohort studies and randomized controlled trials comparing EA and IA available in the literature

\begin{tabular}{|c|c|c|c|c|c|c|c|c|c|c|c|c|}
\hline \multirow[t]{2}{*}{ Author } & \multirow[t]{2}{*}{ Year } & \multirow[t]{2}{*}{ Type } & \multirow[t]{2}{*}{$\begin{array}{l}\text { Studies } \\
\text { included }\end{array}$} & \multicolumn{2}{|c|}{$\begin{array}{c}\text { No. } \\
\text { patients }\end{array}$} & \multirow[t]{2}{*}{ Leak } & \multirow[t]{2}{*}{ SSI } & \multirow[t]{2}{*}{ Bowel } & \multirow[t]{2}{*}{$\begin{array}{l}\text { Hospital } \\
\text { function }\end{array}$} & \multirow[t]{2}{*}{$\begin{array}{l}\text { Pain } \\
\text { stay }\end{array}$} & \multicolumn{2}{|c|}{$\begin{array}{l}\text { Morb Hernia } \\
\text { score }\end{array}$} \\
\hline & & & & IC & EC & & & & & & & \\
\hline Tarta & 2013 & Rev. & CCS & 611 & 231 & NS & IA & $\mathrm{IA}$ & IA & NS & $=$ & NS \\
\hline Carnuccio & 2014 & Rev. & $\mathrm{CCS}+\mathrm{PS}$ & 272 & 212 & $=$ & NS & NS & NS & NS & $=$ & NS \\
\hline Ferocci & 2013 & Rev. & $\mathrm{CCS}+\mathrm{RA}$ & 202 & 223 & $=$ & $=$ & $\mathrm{IA}$ & IA & IA & $=$ & NS \\
\hline Wu & 2017 & Met. & $\mathrm{PS}+\mathrm{RCT}+\mathrm{CA}$ & 994 & 963 & $=$ & $=$ & IA & $\mathrm{IA}$ & NS & $=$ & $=$ \\
\hline Oostendorp & 2017 & Rev. & $\mathrm{CCS}+\mathrm{PS}$ & 763 & 729 & $=$ & IA & $=$ & IA & NS & $I A$ & NS \\
\hline Ricci & 2016 & Rev. & $\mathrm{CCS}+\mathrm{PS}$ & 864 & 853 & $=$ & IA & $=$ & $\mathrm{IA}$ & $=$ & $I A$ & $\mathrm{IA}$ \\
\hline Emile & 2019 & Rev. & $\mathrm{PS}+\mathrm{RCT}$ & 2123 & 2327 & $\mathrm{IA}$ & IA & IA & IA & NS & $I A$ & $\mathrm{IA}$ \\
\hline Allaix & 2019 & RCT & & 70 & 70 & NS & NS & IA & $=$ & IA & $=$ & $=$ \\
\hline Bollo & 2020 & RCT & & 70 & 70 & $=$ & $=$ & $\mathrm{IA}$ & $=$ & IA & $\mathrm{IA}$ & NS \\
\hline
\end{tabular}

"IA" - favors intracorporeal anastomosis group. "=" no difference between IA and EA group

Rev. - review, Met. = meta-analysis, Morb. - morbidity, CCS - case controlled series, RA - retrospective analyses

CA - conference abstracts, PS - Non-randomized prospective studies, RCT - randomized controlled trial

NS - not specified/not statistically significant

ii) limited experience with laparoscopic intracorporeal suturing techniques, as the learning curve was underway at the time; iii) a need for additional stapling devices that increased the overall cost of the procedure.

The extraction site of the transverse supraumbilical mini-laparotomy was routinely placed on the projection line of the transverse colon, centered on the site where the colon will be divided, in order to minimize the distance from the mini-laparotomy to the root of the mesocolon and to the origin of the middle colic artery from the superior mesenteric artery. However, even with these precautions, extraction of the colon outside of the abdominal cavity in obese patients with short, fatty infiltrated mesocolon proved to be challenging and there was a real risk of tear of the left branch of the middle colic vessels during manipulation. In some patients the stump of the transverse colon could not be extracted entirely through the mini-laparotomy and completion of the extracorporeal anastomosis required use of stapling devices which were inserted into the lumen of the ileum and transverse colon and advanced beyond the level of the abdominal fascia to perform and adequately wide ileocolic anastomosis. Due to the limited field of view on the terminal ileum, there was also a real risk of creating a twisted anastomosis if the latter was not correctly placed and manipulated after extracorporeal division.

As our experience in laparoscopic surgery improved, the number of laparoscopic suturing events increased significantly: suture of perforated gastric and duodenal ulcers, wedge or segmental resections of the small bowel with manual suturing for trauma, tumors, intussusception, suture of the peritoneum for TAPP laparoscopic hernia repair, etc. Financial resources also became more generous. The decisive factor in changing our view on the anastomotic technique was the result of extensive discussions with experienced surgeons familiar with the IA technique that addressed our concerns on the risk of intraperitoneal and parietal contamination (11). Finally, in 2017 the first intracorporeal anastomosis was performed by our team and since then it has become our preferred approach. The IA technique offers a number of benefits that we consider to be significant: 1) there is less risk of injury of the transverse colon and its attached mesentery during manipulation for trans-parietal extraction; 2) the colon and ileum can be divided during the various phases of dissection as they no longer have to be attached to the specimen for the extraction phase; 3) there is no risk of misalignment or twisting of the ileal loop during preparation of the 
anastomosis; 4) the specimen can be extracted through a Pfannenstiel mini-laparotomy which is known for its reduced invasiveness and an almost null rate of incisional hernia.

Currently, there are no clear guidelines in the literature regarding the approach recommended for creation of the anastomosis after laparoscopic right colectomy, selection of an extracorporeal or intracorporeal technique depending on the technical abilities and personal preference of the surgeon. Although intracorporeal anastomoses have been performed since the early 1990's (12), significant data on this subject has only recently become available. To date, several systematic reviews, meta-analyses and, more recently, randomized controlled trials analyzed comparatively the outcomes after extracorporeal versus intracorporeal anastomoses (13-19).

The first review published by Tarta et al. in 2013 included 13 case reports and casecontrolled series (13). 814 patients were analyzed in total of which $611(72.8 \%)$ had an IA and $231(27.2 \%)$ an EA anastomosis. The anastomoses were constructed using various side-to-side techniques: isoperistaltic or antiperistaltic, totally stapled or combined stapled and hand-sewn. The IA anastomosis was recommended in patients with thick or retracted/fibrotic mesentery which is difficult to be extracted through the abdominal wall, including obese patients and patients with ileo-colic Crohn's disease. The mesenteric defect was left open in most cases; it was routinely closed only in the study of Fabozzi et al (20). The IA anastomosis offered better results on the overall anastomotic leak rate $(\mathrm{IA}=1 \%$ vs $\mathrm{EA}=2.52 \%)$ and overall rate of surgical site infection (SSI).

In 2014 Carnuccio et al. (14) analyzed 6 case-controlled studies of which two collected data in a prospective manner $(21,22)$. The anastomosis was performed intracorporeally in $57.2 \%$ of the total 484 patients and was associated with shorter time to return of bowel movement, shorter length of hospital stay and better cosmetic results. Data on the incidence of anastomotic fistula was however heterogeneous: 2 studies reported no leaks, 2 authors reported better results with EA (without statistical significance) and 3 studies described a reduced incidence of anastomotic leak with IA, one of these reaching statistical significance (20). A similar study by Feroci et al. comprising 425 patients from 5 non-randomized controlled trials also demonstrated earlier resumption of bowel movements and of solid diet, decreased use of analgesics and a shorter duration of hospital stay in favor of the IA anastomosis (15).

In a more recent meta-analysis which also included a randomized controlled trial, Wu et al. (16) analyzed data on a total of 994 patients with IA (50.8\%) and 963 patients with EA $(49.2 \%)$ and did not observe significant differences concerning operative time, anastomotic leakage, anastomotic bleeding, postoperative ileus, wound infection, intraabdominal abscess formation, mortality or incisional hernia between the two groups. However, IA patients had a shorter hospitalization period, an earlier resumption of oral feeding and a shorter time to first defecation. Included in this review was a paper by Marchesi et al (23) which showed a reduction of the time required to perform the IA anastomosis at the end of his case series indicating that there is indeed a learning curve for the IA anastomosis technique.

A systematic review by v. Oostendorp et al. (17) published in 2017 which included 1492 patients $(\mathrm{IA}=763$ vs $\mathrm{EA}=729)$ confirmed a favorable outcome for the IA patients in terms of short term morbidity: less surgical site infections, shorter hospital stay and earlier return of bowel function.

Ricci et al (18) included two recent papers that proposed a standardized classification system of postoperative complications and added nearly 200 patients per arm to the analyzed population. Their results showed again a significantly lower rate of overall morbidity and wound infection in the IA group.

The most recent systematic review to date by Emile et al (19) analyzed 25 studies comprising 4450 patients (IA $=2123,47.7 \%$ vs. $\mathrm{EA}=2327,52.3 \%$ ), including both laparoscopic (73\%) and robot-assisted approaches (27\%), as 
well as benign $(\mathrm{n}=1077,24.2 \%)$ and malignant cases $(n=3373,75.8 \%)$. In addition to increasing the number of patients analyzed compared to previous reviews, this paper included one prospective cohort study (24) and one randomized trial (25). Interestingly, this review showed significantly higher odds of anastomotic leak rate for the EA anastomosis, among the possible explanations being the increased rate of hand sewn techniques ( $\approx 50 \%)$ as well as that fact that EA required greater colonic mobilization and increased traction on the mesentery. There was also a higher risk of developing SSI in EA patients in accordance with the findings of Ricci et. al. (18) but unlike other reports $(15,16)$ while the IA technique was associated with a significantly reduced length of stay (18). The incidence of postoperative incisional hernia was also higher for the extracorporeal anastomosis.

Two recent randomized controlled trials showed marginally better outcome for the IA anastomosis. Analyzing 140 patients, Allaix et al (26) showed that the IA anastomosis was indeed associated with faster recovery of bowel function but this advantage was not reflected in the postoperative length of stay. No significant differences were observed in the length of skin incision, 30-day morbidity, reoperation or readmission rate. In the other trial on another 14 patients, Bollo et al (27) observed that the IA anastomosis was associated with less postoperative pain, earlier recovery of bowel function, decreased incidence of paralytic ileus and a significantly reduced rate of grade I and II complications according to the Clavien-Dindo classification system. The anastomotic leak rate was higher in the IA patients $(8.6 \%$ vs. $2.9 \%)$, although this finding was not statistically significant.

In summary, the current available evidence does not have the scientific power to validate a certain recommendation on the use of IA or EA for reconstruction of the digestive tract after laparoscopic right hemicolectomy. However, the present data shows that patients from the IA group generally resume their bowel movements faster, have less pain and leave the hospital earlier when compared to the EA group. Some papers also report a reduced incidence of SSI in IA patients, decreased overall morbidity and a significantly lower risk of incisional hernia. The rate of anastomotic insufficiency does not seem to differ between the two groups. Several randomized controlled trials are currently under way on this topic (e.g. NCT03990714; NCT03422588; NCT03130166; NCT01453556; NCT02667860 and the RICART Study - NCT03862781) and hopefully they will give us a more definite answer regarding the optimal approach for creation of the anastomosis after laparoscopic right colectomy.

When our results are compared with data from the literature, the most striking difference is the significantly increased rate of SSI in the IA group vs EA group. It is a rather unexpected finding which can be explained by the routine placement of the Pfannenstiel incision into a suprapubic fold which, in overtly obese patients, is sometimes quite deep and, probably, more prone to SSI. Placing the transversal incision to a more cephalad position could reduce the incidence of this complication in the future although the trade-off will be a less favorable cosmetic effect. In our cohort of patients SSI was managed with immediate surgical debridement and vacuum therapy and, although it significantly increased the length of hospital stay in the IA group, it did not increase the risk of incisional hernia on the long-term follow-up.

This study has a number of flaws that need to be recognized: i) the number of patients included in the analysis is obviously too low to draw conclusions but, on the other hand, by analyzing patients operated by a single surgical team, the bias residing from lack of anastomotic technique standardization was avoided; ii) data was not collected in a prospective manner and therefore there are no records on the time to first flatus or first solid food intake to show whether one technique is superior to the other in this respect. However, the lack of this data does not prevent from acknowledging that the IA anastomosis has certain advantages related to the technique 
itself as the colonic stump is no longer manipulated through the abdominal wall, there is less risk of injury to its vasculature and the operation can be carried out without the need for an extraperitoneal phase. Moreover, the ileum is easily visible before the anastomosis is created and consequently the risk of anastomotic torsion is reduced. For these reasons we are now in favor of the intracorporeal anastomosis, especially for obese patients with thick, fatty infiltration of the transverse mesocolon. The IA anastomosis does require completion of a specific learning curve but that can be shortened by experience accumulated from other types of surgeries, as was our case. However, the extracorporeal anastomosis approach should not be disregarded and remains an adequate choice for surgical teams experienced in open surgery and for surgeons who are at the beginning stages of laparoscopic colorectal surgery practice or have not yet completed the learning curve required for the intracorporeal anastomosis.

\section{Conclusions}

In conclusion, each surgeon should perform the type of anastomosis which they feel most comfortable with, as both open and laparoscopic IA and EA techniques offer excellent results. However, with the continuous development of advanced laparoscopic techniques, an increasing number of surgical teams now have the possibility to perform an IA anastomosis and for many it has become the technique of choice. The IA anastomosis seems to facilitate a faster postoperative return of bowel function, reduced postoperative pain, decreased morbidity, a shorter hospital stay and a lower rate of incisional hernia while preserving the low incidence rate of anastomotic leak specific for the extracorporeal anastomosis. In addition, this technique might be more suitable for obese patients. However, based on the data currently available in the literature it can not be concluded that IA should be adopted as the standard of care for laparoscopic right colectomy. The results of ongoing randomized controlled trials might bring more clarity on this issue in the future.

\section{Conflict of Interest}

The authors declare no conflicts of interests.

\section{References}

1. Torre L, Bray F, Siegel R, Ferlay J, Lortet-Tieulent J, Jemal A. Global cancer statistics, 2012. CA Cancer J Clin. 2015;65(2):87-108.

2. Veldkamp R, Kuhry E, HopWC, Jeekel J, Kazemier G, Bonjer HJ, et al. Laparoscopic surgery versus open surgery for colon cancer: short-term outcomes of a randomised trial. Lancet Oncol. 2005; 6(7):477-84

3. Laparoscopically assisted colectomy is as safe and effective as open colectomy in people with colon cancer Abstracted from: Nelson H, Sargent D, Wieand HS, et al; for the Clinical Outcomes of Surgical Therapy Study Group. A comparison of laparoscopically assisted and open colectomy for colon cancer. N Engl J Med 2004; 350: 2050-2059. Comment in Cancer Treat Rev. 2004;30(8):707-9.

4. Guillou P, Quirke P, Thorpe H, Walker J, Jayne D, Smith A, et al. Short-term endpoints of conventional versus laparoscopic-assisted surgery in patients with colorectal cancer (MRC CLASSICC trial): multicenter, randomized controlled trial. Lancet. 2005;365(9472): 1718-26.

5. Ding J, Liao GQ, Xia Y, Zhang ZM, Liu S, Yan ZS. Laparoscopic versus open right hemicolectomy for colon cancer: a meta-analysis. J Laparoendosc Adv Surg Tech A. 2013;23(1):8-16.

6. Zheng MH, Feng B, Lu AG, Jian-Wen Li, Wang ML, Mao ZH, et al. Laparoscopic versus open right hemicolectomy with curative intent for colon carcinoma. World J Gastroenterol. 2005;11(3):323-6.

7. Garmpis N, Dimitroulis D, Garmpi A, Diamantis E, Spartalis E, Schizas D, et al. Enhanced Recovery After Surgery: Is It Time to Change Our Strategy Regarding Laparoscopic Colectomy? In Vivo. 2019;33(3):669-674.

8. Jackson TD, Kaplan GG, Arena G, Page JH, Rogers SO Jr Laparoscopic versus open resection for colorectal cancer: a metaanalysis of oncologic outcomes. J Am Coll Surg. 2007;204(3):439

9. Siddiqui MR, Sajid MS, Khatri K, Cheek E, Baig MK Elective open versus laparoscopic sigmoid colectomy for diverticular disease: a meta-analysis with the Sigma trial. World J Surg. 2010;34(12): 2883-901.

10. Bartels SA, Gardenbroek TJ, Ubbink DT, Buskens CJ, Tanis PJ, Bemelman WA Systematic review and meta-analysis of laparoscopic versus open colectomy with end ileostomy for non-toxic colitis. Br J Surg. 2013;100(6):726

11. Copaescu C, Smeu B, Filip S, Hutopila I, Priboi M. Intracorporeal anastomosis after laparoscopic right colectomy. Conference; Romanian Society of Coloproctoloy Congress, lasi. (18-20 April 2013).

12. Jacobs M, Verdeja JC, Goldstein HS. Minimally invasive colon resection (laparoscopic colectomy). Surg Laparosc Endosc. 1991; 1(3):144-50.

13. C Tarta, M Bishawi, R Bergamaschi. Intracorporeal ileocolic anastomosis: a review. Tech Coloproctol. 2013;17(5):479-85.

14. Carnuccio P, Jimeno J, Parés D. Laparoscopic right colectomy: a systematic review and meta-analysis of observational studies comparing two types of anastomosis. Tech Coloproctol. 2014; 18(1):5-12.

15. Feroci $F$, Lenzi E, Garzi A, Vannucchi A, Cantafio S, Scatizzi M Intracorporeal versus extracorporeal anastomosis after laparoscopic right hemicolectomy for cancer: a systematic review and meta-analysis. Int J Colorectal Dis. 2013;28(9):1177-86.

16. Wu Q, Jin C, Hu T, Wei M, Wang Z. Intracorporeal versus extra- 
corporeal anastomosis in laparoscopic right colectomy: a systematic review and meta-analysis. J Laparoendosc Adv Surg Tech A. 2017;27(4):348-357.

17. van Oostendorp S, Elfrink A, Borstlap W, Schoonmade L, Sietses C Meijerink J, et al. Intracorporeal versus extracorporeal anastomosis in right hemicolectomy: a systematic review and meta-analysis. Surg Endosc. 2017;31(1):64-77. Epub 2016 Jun 10.

18. Ricci C, Casadei R, Alagna V, Zani E, Taffurelli G, Pacilio CA, et al. A critical and comprehensive systematic review andmeta-analysis of studies comparing intracorporeal and extracorporeal anastomosis in laparoscopic right hemicolectomy. Langenbecks Arch Surg. 2017;402(3):417-427. Epub 2016 Sep 5.

19. Emile SH, Elfeki H, Shalaby M, Sakr A, Bassuni M, Christensen P, et al. Intracorporeal versus extracorporeal anastomosis in minimally invasive right colectomy: an updated systematic review and metaanalysis. Tech Coloproctol. 2019;23(11):1023-1035.

20. Fabozzi M, Allieta R, Contul RB, Grivon M, Millo P, Lale-Murix E, et al. Comparison of short- and medium-term results between laparoscopically assisted and totally laparoscopic right hemicolectomy: a case-control study. Surg Endosc. 2010;24(9):2085-91.

21. Scatizzi M, Kroning KC, Borrelli A, Andan G, Lenzi E, Feroci F. Extracorporeal versus intracorporeal anastomosis after laparoscopic right colectomy for cancer: a case-control study. World J Surg. 2010; 34:2902-2908
22. Vignali A, Bissolati M, De Nardi P, Di Palo S, Staudacher C. Extracorporeal vs. intracorporeal ileocolic stapled anastomoses in laparoscopic right colectomy: An interim analysis of a randomized clinical trial. J Laparoendosc Adv Surg Tech A. 2016;26(5):343-8.

23. Marchesi F, Pinna F, Percalli L, Cecchini S, Riccó M, Costi R, et al. Totally laparoscopic right colectomy: Theoretical and practical advantages over the laparo-assisted approach. J Laparoendosc Adv Surg Tech A. 2013;23(5):418-24.

24. Erguner I, Aytac E, Baca B, Hamzaoglu I, Karahasanoglu T. Total laparoscopic approach for the treatment of right colon cancer: a technical critique. Asian J Surg. 2013;36(2):58-63.

25. Mari GM, Crippa J, Costanzi ATM, Pellegrino R, Siracusa C, Berardi $V$, et al. Intracorporeal Anastomosis Reduces Surgical Stress Response in Laparoscopic Right Hemicolectomy: A Prospective Randomized Trial. Surg Laparosc Endosc Percutan Tech. 2018; 28(2):77-81

26. Allaix ME, Degiuli M, Bonino MA, Arezzo A, Mistrangelo M, Passera $\mathrm{R}$, et al. Intracorporeal or extracorporeal ileocolic anastomosis after laparoscopic right colectomy: a double-blinded randomized controlled trial. Ann Surg. 2019;270(5):762-67.

27. Bollo J, Turrado V, Rabal A, Carrillo E, Gich I, Martinez MC, et al. Randomized clinical trial of intracorporeal versus extracorporeal anastomosis in laparoscopic right colectomy (IEA trial). Br J Surg. 2020;107(4):364-372. 